Article

\title{
Effect of WC Grain Size and Abrasive Type on the Wear Performance of HVOF-Sprayed WC-20Cr $\mathrm{C}_{2}-7 \mathrm{Ni}$ Coatings
}

\author{
Qun Wang ${ }^{1}$, Yingpeng Zhang ${ }^{1}$, Xiang Ding ${ }^{2, *}$, Shaoyi Wang ${ }^{3}$ and \\ Chidambaram Seshadri Ramachandran ${ }^{4}$ \\ 1 College of Materials Science and Engineering, Hunan University, Changsha 410082, China; \\ wangqun@hun.edu.cn (Q.W.); z2290064405@163.com (Y.Z.) \\ 2 School of Energy and Power Engineering, Wuhan University of Technology, Wuhan 430063, China \\ 3 Chongyi Zhangyuan Tungsten Co., Ltd., Ganzhou 341300, China; zywsy@zy-tungsten.com \\ 4 Department of Materials Science and Engineering, The State University of New York (SUNY) @ Stony Brook, \\ New York, NY 11794, USA; csrcn1@gmail.com \\ * Correspondence: xiang.ding@whut.edu.cn; Tel.: +86-27-86581992
}

Received: 9 June 2020; Accepted: 6 July 2020; Published: 9 July 2020

check for updates

\begin{abstract}
In order to investigate the effect of WC grain size on coatings' properties and abrasive wear performance, a few WC-20Cr $\mathrm{C}_{2}$-7Ni coatings with three different $\mathrm{WC}$ grain sizes were deposited by the high-velocity oxy-fuel (HVOF) thermal spray process. The phase compositions, microstructures, and mechanical properties of the coatings were investigated. Furthermore, the two- and three-body abrasive wear performances of the three coatings were tested by using $\mathrm{SiC}$ and $\mathrm{SiO}_{2}$ abrasives, respectively. The results show that all the three coatings were composed of $\mathrm{WC}_{1} \mathrm{Cr}_{3} \mathrm{C}_{2}$, and the $\mathrm{Ni}$ binder as well as the $(\mathrm{W}, \mathrm{Cr})_{2} \mathrm{C}$ phase. The abrasive wear resistance of the $\mathrm{WC}-20 \mathrm{Cr}_{3} \mathrm{C}_{2}-7 \mathrm{Ni}$ coating monotonously increased with increasing WC grain size when the $\mathrm{SiC}$ abrasive was used in the twoand three-body abrasive wear tests. However, the wear resistance trend was reversed when the $\mathrm{SiO}_{2}$ abrasive was used in the three-body abrasive wear test. The specific wear rate of the $\mathrm{WC}-20 \mathrm{Cr}_{3} \mathrm{C}_{2}-7 \mathrm{Ni}$ coating exposed to the SiC abrasive under the two-body abrasive wear test was the largest. The wear resistance of the coatings was more significantly affected by the hardness of the abrasive particles than the size of carbides present within the coating. The high hardness of SiC can cut both the carbide and the binder phase of the WC-based cermet coatings, resulting in a high wear rate, whereas the low hardness of $\mathrm{SiO}_{2}$ cuts and/or scratches the binder initially, and then it dislodges the carbides from the matrix. The dislodged carbides which were subsequently pulled out from the matrix by the repeated impact of the $\mathrm{SiO}_{2}$ abrasives result in a milder wear rate.
\end{abstract}

Keywords: $\mathrm{HVOF}$; WC-20Cr${ }_{3} \mathrm{C}_{2}-7 \mathrm{Ni}$ coating; WC size; two-body abrasive wear; three-body abrasive wear

\section{Introduction}

High-velocity oxy-fuel (HVOF) spraying has been widely used to deposit dense tungsten carbide (WC)-based coatings with high hardness and excellent wear resistance, which are used in a range of industrial applications for wear protection under different service conditions [1-4]. WC-based cermet powders are usually composed of a primary WC phase, with metal binders such as Co, $\mathrm{Cr}$, and Ni. Some of the most commonly used powders are WC-12Co, WC-17Co, WC-10Co4Cr, WC-10Ni, and WC-20C $\mathrm{r}_{3} \mathrm{C}_{2}-7 \mathrm{Ni}$ (compositions in weight percent). The WC-10Co4Cr coatings typically exhibit better corrosion resistance than WC-12Co or WC-17Co coatings as due to the addition of 4 wt.\% Cr [5,6]. Unlike standard WC-based powders, WC-20C $\mathrm{r}_{3} \mathrm{C}_{2}-7 \mathrm{Ni}$ incorporates two kinds of carbides, namely WC 
and $\mathrm{Cr}_{3} \mathrm{C}_{2}$, which were considered to bridge the gap between WC-Co(Cr) and $\mathrm{Cr}_{3} \mathrm{C}_{2}-\mathrm{NiCr}$ [7] coatings due to the excellent oxidation and corrosion resistance of $\mathrm{Cr}_{3} \mathrm{C}_{2}$ [8-10]. Some studies have shown that WC-20Cr $\mathrm{C}_{2}-7 \mathrm{Ni}$ coatings are characterized by a significantly higher oxidation resistance than other WC-based coatings [11], which can be attributed to the formation of a compact and protective oxide layer consisting of $\mathrm{Cr}_{2} \mathrm{O}_{3}, \mathrm{NiO}$, and their spinels $\left(\mathrm{NiCr}_{2} \mathrm{O}_{4}\right.$ and $\left.\mathrm{NiWO}_{4}\right)$ [12]. Further, the post-spray heat treatment in air increased the oxidation on the coating surface significantly, which can reduce the wear of the cermet coating as a result of formation of fine oxide particles transferred on to the wear track of the coating $[13,14]$.

Besides chemical composition, the performance of the HVOF-sprayed WC-based cermet coatings strongly depends on the morphological properties of the powder, such as the size distribution $[15,16]$ and apparent density [17] as well as the original carbide grain sizes [18-20]. It has been proposed that carbide grain size is one of the most crucial parameters that can affect the mechanical properties and wear performance of carbide-based cermet coatings [21]. Usmani et al. [22] found that the abrasive wear resistance of HVOF-sprayed WC-17Co coatings increases with the increase in WC size. Kumari et al., however, found that the abrasive wear rate of a HVOF-sprayed WC-12Co coating was not only affected by WC size but also influenced by the binder mean free path [23].

Since the wear mechanisms of the WC-Co coating are different between abrasive wear and sliding wear, it is important to employ representative test methods and wear media to mimic realistic service conditions. One of the critical testing variables in abrasion evaluation is the abrasive media or type, whose hardness may be softer or harder than that of the coating material. However, measurement of the abrasive wear resistance of HVOF-sprayed cermet coatings has been typically conducted by dry and wet sand rubber wheel abrasive wear tests with a low-hardness $\mathrm{SiO}_{2}$ [24] or titania sand abrasive [21]. In the literature, there is minimal past work concerning the differences between two-body and three-body abrasive wear testing of WC-based cermet coatings by using higher hardness $\mathrm{SiC}$ abrasives. Further, the composition of $\mathrm{WC}-20 \mathrm{Cr}_{3} \mathrm{C}_{2}-7 \mathrm{Ni}$ has been known for more than a half-century, but the coating properties have been studied much less intensively than those of other carbide-based coatings such as WC-Co, WC-Co-Cr, and $\mathrm{Cr}_{3} \mathrm{C}_{2}-\mathrm{NiCr}$ coatings.

In order to better reflect the service performance of the WC-20Cr${ }_{3} \mathrm{C}_{2}-7 \mathrm{Ni}$ coatings under working terms through the lab-tested abrasive wear results, a better understanding of the wear mechanism of the coatings is required, which can be utilized as a reference for both the development and application of the coating material. In this work, three $\mathrm{WC}-20 \mathrm{Cr}_{3} \mathrm{C}_{2}-7 \mathrm{Ni}$ coatings with nominally fine, medium, and coarse WC grains were prepared by an HVOF spray system. Furthermore, the effect of WC grain size and abrasive type on the HOVF-sprayed WC- $20 \mathrm{Cr}_{3} \mathrm{C}_{2}-7 \mathrm{Ni}$ coatings, as well as wear test methods, have been investigated in detail.

\section{Materials and Methods}

\subsection{Materials}

Three WC-20 $\mathrm{Cr}_{3} \mathrm{C}_{2}-7 \mathrm{Ni}$ powders with the same nominal chemical composition (wt.\%, WC: 73, $\mathrm{Cr}_{3} \mathrm{C}_{2}: 20, \mathrm{Ni}$ : 7) were produced by using the agglomeration and sintering process (Chongyi Zhangyuan Tungsten Co., Ltd., Ganzhou, China). The powder code, characteristics, and average sizes of the raw carbides and Ni particles are shown in Table 1.

Table 1. Powder designation code, characteristics, and average size of the raw ceramic and Ni particles.

\begin{tabular}{|c|c|c|c|c|c|}
\hline $\begin{array}{l}\text { Designation } \\
\text { Code }\end{array}$ & $\begin{array}{c}\text { WC Size } \\
(\mu \mathrm{m})\end{array}$ & $\begin{array}{c}\mathrm{Cr}_{3} \mathrm{C}_{2} \\
\operatorname{Size}(\mu \mathrm{m})\end{array}$ & $\begin{array}{l}\text { Ni Size } \\
(\mu \mathrm{m})\end{array}$ & $\begin{array}{l}\text { Size Distribution } \\
(\mu \mathrm{m})\end{array}$ & $\begin{array}{l}\text { Apparent Density } \\
\left(\mathrm{g} / \mathrm{cm}^{3}\right)\end{array}$ \\
\hline $\mathrm{FP}$ & 0.8 & 5 & 9 & $15-45$ & 4.41 \\
\hline $\mathrm{MP}$ & 2.5 & 5 & 9 & $15-45$ & 4.42 \\
\hline $\mathrm{CP}$ & 8 & 5 & 9 & $15-45$ & 4.24 \\
\hline
\end{tabular}


From Table 1,it can be found that all three powders have similar characteristics except WC grain size. The surface and cross-sectional morphologies of the three $\mathrm{WC}-20 \mathrm{Cr}_{3} \mathrm{C}_{2}-7 \mathrm{Ni}$ powders are shown in Figure 1.
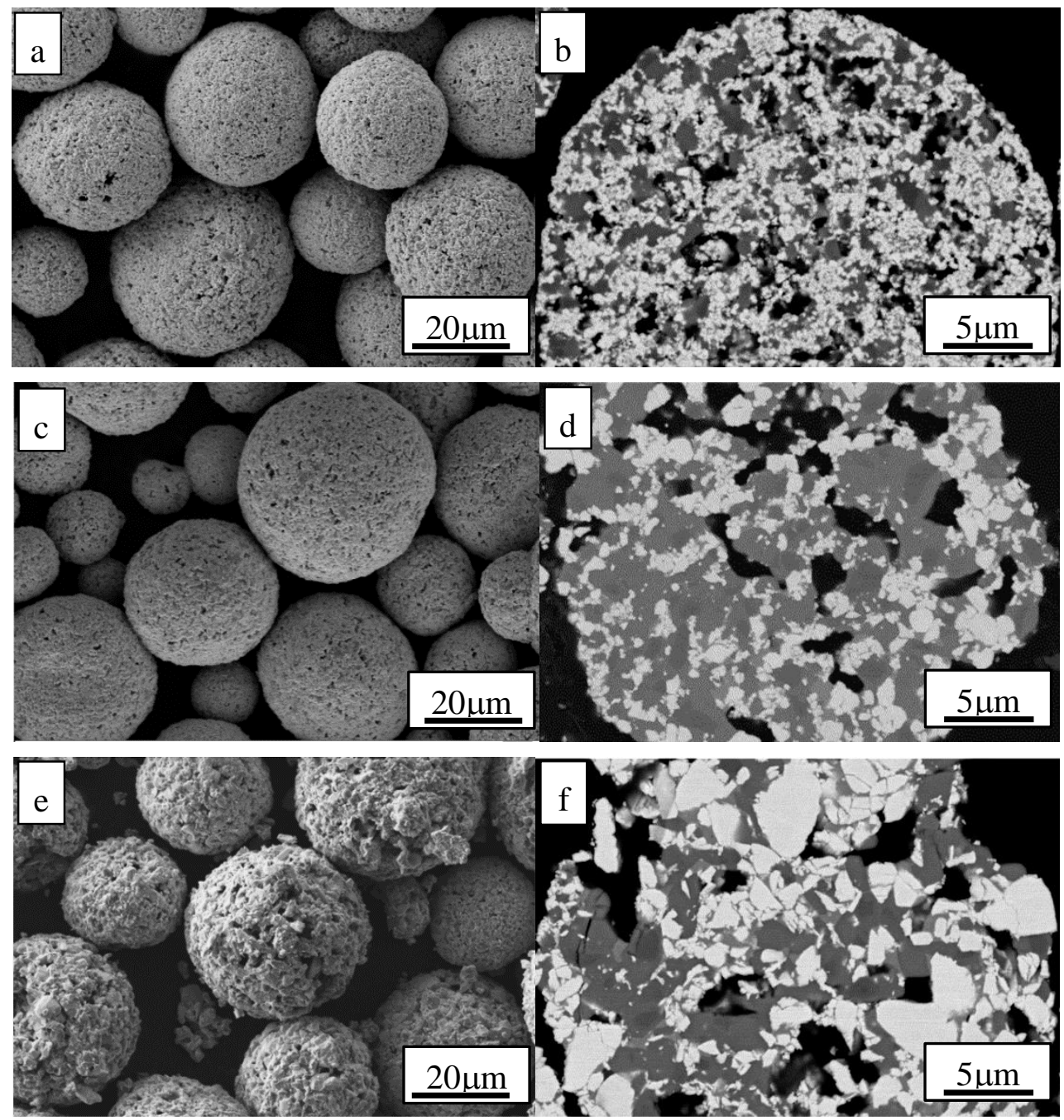

Figure 1. Surface morphologies of the $(\mathbf{a}, \mathbf{b}) \mathrm{FP} ;(\mathbf{c}, \mathbf{d}) \mathrm{MP}$ and $(\mathbf{e}, \mathbf{f}) \mathrm{CP}$ powders.

The three $\mathrm{WC}-20 \mathrm{Cr}_{3} \mathrm{C}_{2}-7 \mathrm{Ni}$ powders were of spherical or near-spherical shape with some pores on their surfaces. The FP and MP powders showed a smoother surface than that of the CP powder. The rough surface of the CP powder was associated with its large WC grain size.

The white, grey, and dark grey phases shown in the back scattered electron (BSE) images of the cross-sectional morphologies (Figure $1 \mathrm{~b}$ ) were supposed to be $\mathrm{WC}, \mathrm{Ni}$, and $\mathrm{Cr}_{3} \mathrm{C}_{2}$ as a result of their different atomic weight, which will be discussed later.

\subsection{Coating Preparation}

The FP, MP, and CP powders were sprayed on degreased and sandblasted low-carbon steel substrates using JP8000 HVOF (Praxair Surface Technologies Inc., Indianapolis, IN, USA) with a barrel length of $152.4 \mathrm{~mm}$. The resulting coatings were designated as FC, MC, and CC, respectively. The spraying parameters of the three $\mathrm{WC}-20 \mathrm{Cr}_{3} \mathrm{C}_{2}-7 \mathrm{Ni}$ powders were kept identical and were developed based on practical experience and previous work $[25,26]$. The coating deposition conditions are presented in Table 2. 
Table 2. Spraying parameters of the three WC-20Cr3C2-7Ni powders.

\begin{tabular}{ccccccc}
\hline $\begin{array}{c}\text { Kerosene } \\
(\mathrm{L} / \mathbf{h})\end{array}$ & $\begin{array}{c}\text { Oxygen } \\
\left(\mathbf{m}^{3} / \mathbf{h}\right)\end{array}$ & $\begin{array}{c}\text { Carrier Gas } \\
\left(\mathbf{m}^{3} / \mathbf{h}\right)\end{array}$ & $\begin{array}{c}\text { Step } \\
(\mathbf{m m})\end{array}$ & $\begin{array}{c}\text { Velocity } \\
(\mathbf{m m} / \mathbf{s})\end{array}$ & $\begin{array}{c}\text { Spraying } \\
\text { Distance }(\mathbf{m m})\end{array}$ & $\begin{array}{c}\text { Feed Rate } \\
(\mathrm{g} / \mathbf{m i n})\end{array}$ \\
\hline 24.6 & 56.6 & 0.65 & 5 & 500 & 380 & 70 \\
\hline
\end{tabular}

The spray plume was perpendicular to the substrate surface, and the substrate temperature was kept below $160^{\circ} \mathrm{C}$ during spraying by using intermittent spraying and intensive compressed air cooling.

\subsection{Characterization}

The X-ray diffraction (XRD) measurements of the WC-20Cr $\mathrm{C}_{3} \mathrm{C}_{2}-7 \mathrm{Ni}$ powders and corresponding coatings were carried out by using a RigakuD/max-2550 diffraction meter (Rigaku Corporation, Tokyo, Japan) with a $\mathrm{Cu}-\mathrm{K} \alpha$ radiation source. Micro-morphologies of the $\mathrm{WC}-20 \mathrm{Cr}_{3} \mathrm{C}_{2}-7 \mathrm{Ni}$ powders, the coating surfaces, and the abrasives used in this work were investigated by using an FEI-Quanta200 (FEI Company, Eindhoven, The Netherlands). An Olympus GX 51 optical microscope (Olympus Corporation, Tokyo, Japan) with an image analysis system was employed to measure the porosity of the WC-20Cr $\mathrm{C}_{2}-7 \mathrm{Ni}$ coatings using cross-section images with 200 times magnification. The indentation method was used to test the hardness and the fracture toughness of the WC- $20 \mathrm{Cr}_{3} \mathrm{C}_{2}-7 \mathrm{Ni}$ coatings with a load of 0.3 and $5 \mathrm{~kg}$, respectively. The coating fracture toughness value was obtained by using the Evans and Wilshaw equation [27]. The results of the porosity, hardness, and fracture toughness of the coatings were reported by the average and standard deviation of ten measurements.

\subsection{Abrasion Wear Tests}

\subsubsection{Two-body Abrasion Wear Test}

Two-body abrasive wear tests were conducted on $40 \times 35 \times 5.3 \mathrm{~mm}^{3}$ rectangular specimens using an NUS-ISO-3 Suga abrasion tester (Suga Instruments, Tokyo, Japan), whose schematic is shown in Figure 2. A $158 \times 12 \mathrm{~mm}^{2} \mathrm{SiC}$ sandpaper (180-mesh) was secured on to a stainless steel wheel $(\phi$ $50 \mathrm{~mm} \times 12 \mathrm{~mm}$ ), to serve as the abrasive counter-body. The specimen was fixed with a locking arrangement against the sandpaper. The coating specimens were subjected to a reciprocating motion with a displacement distance of $35 \mathrm{~mm}$ over the wheel so that the abrasive particles were in contact with the coating surface. A load of $29.4 \mathrm{~N}$ over the specimen was applied through a cantilever mechanism. The wheel rotates $0.8^{\circ}$ as the sample completes one cycle of reciprocating motion, which provides a fresh abrasive surface for wear. The SiC sandpaper was changed at the end of every 400 cycles, and the mass loss was measured after 1600 double strokes (DS).

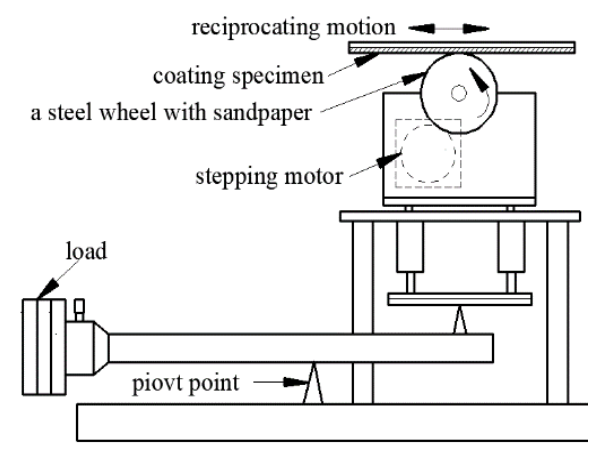

Figure 2. Schematic diagram of the two-body abrasive wear test apparatus. 


\subsubsection{Three-body Abrasion Wear Test}

Three-body abrasive wear tests were conducted on $58 \times 26.5 \times 5.3 \mathrm{~mm}^{3}$ rectangular specimens using an MLS-225-type wet sand/rubber wheel abrasion tester (Zhangiiakou Chengxin Testing Equipment Manufacturing Co., Ltd, Zhangjiakou, China) designed according to the ASTM G105, whose schematic is shown in Figure 3.

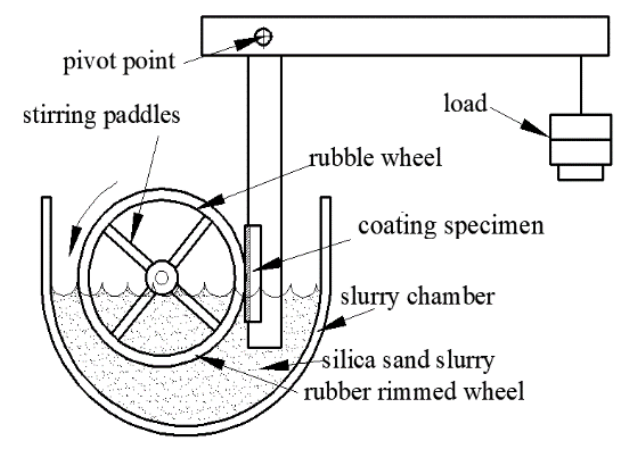

Figure 3. Schematic diagram of the three-body abrasive wear test apparatus.

For the three-body abrasion tests, the coating specimens were submerged in two different kinds of slurry. The first slurry was composed of $1.5 \mathrm{~kg}$ of $\mathrm{SiO}_{2}$ and $1 \mathrm{~kg}$ of water, while the other slurry was formed with $2.18 \mathrm{~kg}$ of $\mathrm{SiC}$ abrasive and $1 \mathrm{~kg}$ of water. More $\mathrm{SiC}$ abrasive was used in the 2nd slurry to achieve the same abrasive concentration loading, due to the higher density of $\operatorname{SiC}\left(3.2 \mathrm{~g} / \mathrm{cm}^{3}\right)$ compared with the $\mathrm{SiO}_{2}$ one $\left(2.2 \mathrm{~g} / \mathrm{cm}^{3}\right)$. Tests lasted for 3600 revolutions, and the applied load was $100 \mathrm{~N}$. Coatings were ultrasonically cleaned with alcohol for $10 \mathrm{~min}$ before and after the two- and three-body abrasive wear test, and then dried by a stream of hot air.

The micro-morphologies of the $180-$ mesh $\mathrm{SiO}_{2}$ and $\mathrm{SiC}$ abrasives, as well as 180 -mesh $\mathrm{SiC}$ sandpaper used in this work, are shown in Figure 4. Three separate samples were subjected to two- and three-body abrasive wear testing for each of the WC-20C $\mathrm{Cr}_{3} \mathrm{C}_{2}-7 \mathrm{Ni}$ coatings. Mass loss was measured using an FA1004 dynamic balance with an accuracy of $0.1 \mathrm{mg}$, and the average value was recorded. The specific wear rate of the coating was obtained by dividing the average weight loss by the theoretical density $\left(13.37 \mathrm{~g} / \mathrm{cm}^{3}\right)$ of the WC- $20 \mathrm{Cr}_{3} \mathrm{C}_{2}-7 \mathrm{Ni}$ coating, wear distance, and the applied load. Figure 4 suggests that the sizes of the $\mathrm{SiC}$ and the $\mathrm{SiO}_{2}$ abrasive are similar, but $\mathrm{SiC}$ abrasives have sharper edges compared with $\mathrm{SiO}_{2}$.

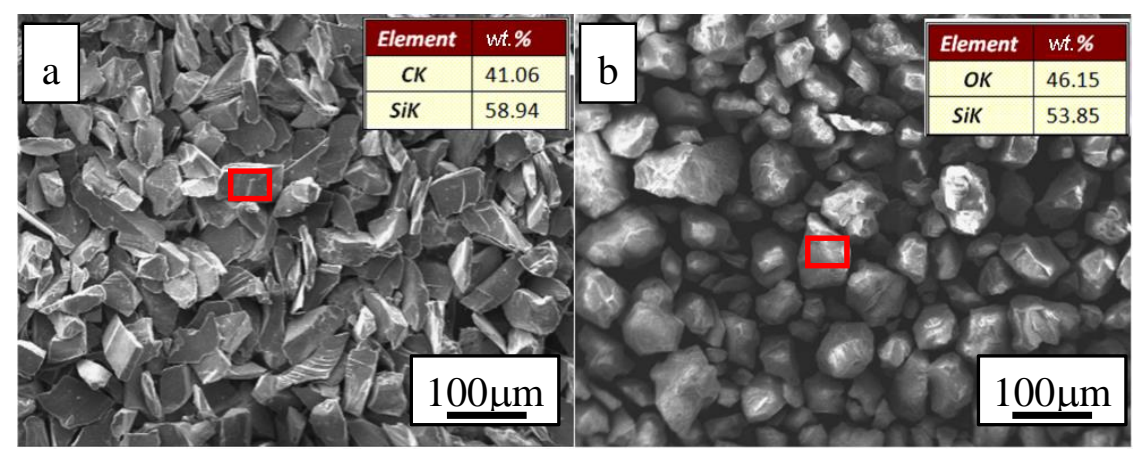

Figure 4. Cont. 


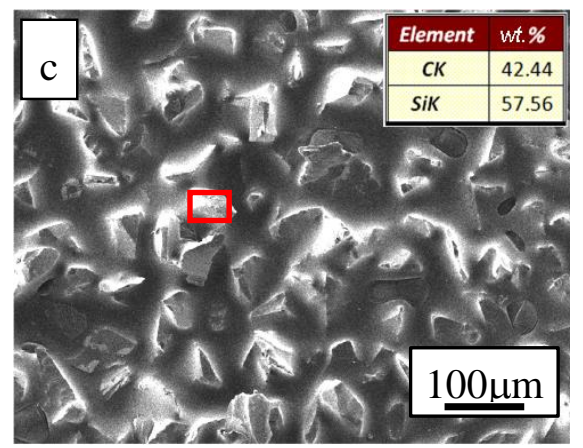

Figure 4. The morphologies of the 180-mesh $\mathrm{SiC}$ and $\mathrm{SiO}_{2}$ abrasives: (a) $\mathrm{SiC}$; (b) $\mathrm{SiO}_{2}$, and (c) $\mathrm{SiC}$ sandpaper. The insert in each image is the EDS result of the abrasive marked by the rectangle.

\section{Experimental Results}

\subsection{The Phase Composition of the Three WC-20Cr $r_{3} \mathrm{C}_{2}-7 \mathrm{Ni}$ Coatings}

The XRD patterns of the WC-20Cr${ }_{3} \mathrm{C}_{2}-7 \mathrm{Ni}$ powder and coatings are shown in Figure 5.

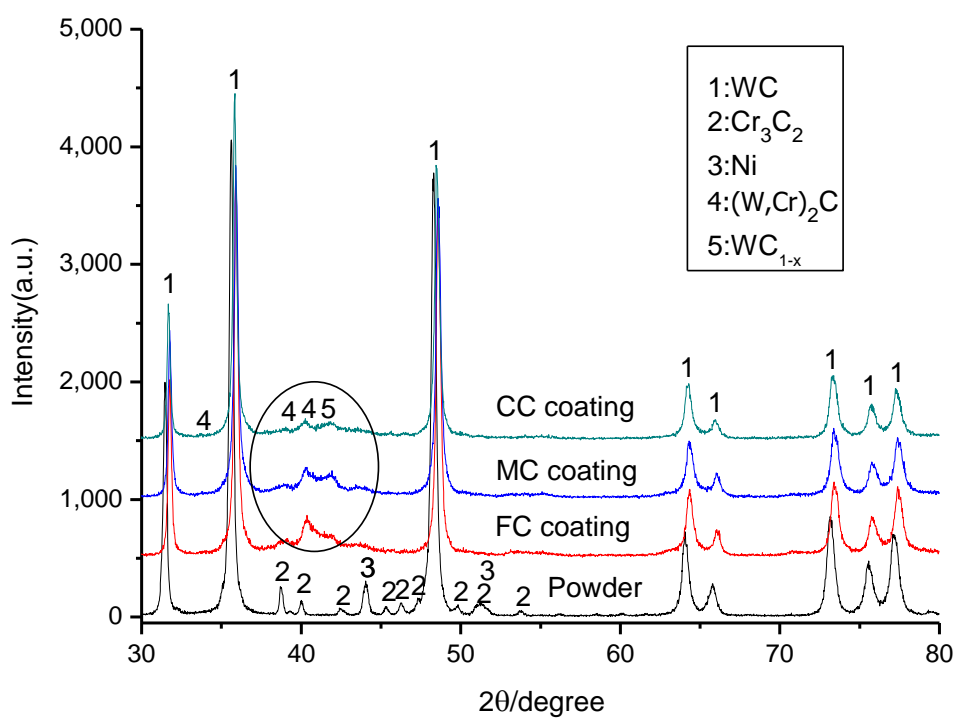

Figure 5. XRD patterns of the $\mathrm{WC}-20 \mathrm{Cr}_{3} \mathrm{C}_{2}-7 \mathrm{Ni}$ powder and coatings.

The diffraction patters of the three coatings are nearly the same, which were composed of the main WC peaks and minor peaks including $(\mathrm{W}, \mathrm{Cr})_{2} \mathrm{C}, \mathrm{Cr}_{3} \mathrm{C}_{2}$ and the amorphous binder phase. Compared with the starting powders, the $\mathrm{Ni}$ binder was barely detected in all as-sprayed $\mathrm{WC}-20 \mathrm{Cr}_{3} \mathrm{C}_{2}-7 \mathrm{Ni}$ coatings. The disappearance of the crystalline Ni phase in the corresponding coatings can be ascribed to the rapid cooling and generation of the amorphous Ni phase in the $2 \theta$ range of $37^{\circ} \sim 46^{\circ}$ (marked by an ellipse in Figure 5). The vanishing of the binder phases has also frequently been reported in other HVOF-sprayed WC-based cermet coatings [21,28]. Moreover, the formation of $(\mathrm{W}, \mathrm{Cr})_{2} \mathrm{C}$ in the coatings as a second carbide phase with intensities that overwhelm the $\mathrm{Cr}_{3} \mathrm{C}_{2}$ phase suggests that the W/Cr ratio has undergone severe stoichiometric change during the spraying process. The generation of the $(\mathrm{W}, \mathrm{Cr})_{2} \mathrm{C}$ phase is the result of several high-temperature metallurgical reactions which may occur even during the sintering process [29]. It is also worth noting that the $(\mathrm{W}, \mathrm{Cr})_{2} \mathrm{C}$ phase becomes more significant with decreased WC grain size. The reason for this is that fine WC particles have larger surface area to volume ratios, leading to higher particle temperatures and thus higher decarburization and metallurgical reactions. 


\subsection{The Cross-Sectional Surface of the Three WC-20Cr $r_{3} C_{2}-7 N i$ Coatings}

The cross-sectional microstructures of the FC, MC, and CC coatings are shown in Figure 6.
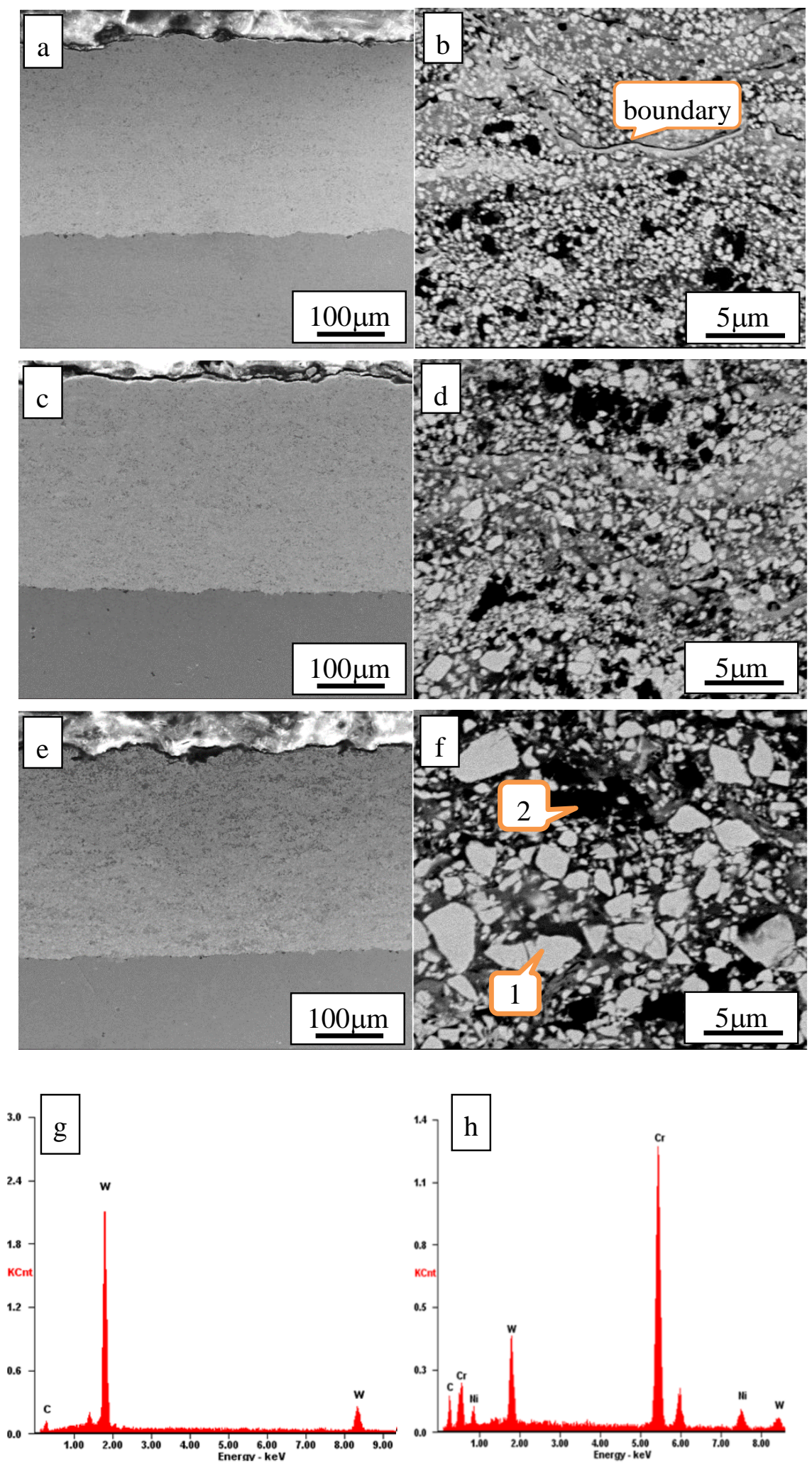

Figure 6. Cross-sectional microstructures of the (a,b) FC, (c,d) MC, and (e,f) CC coatings, (g,h) EDS results of the " 1 " and " 2 " marked in (f). 
It is observed from Figure $6 \mathrm{a}, \mathrm{c}, \mathrm{e}$ that all the three $\mathrm{WC}-20 \mathrm{Cr}_{3} \mathrm{C}_{2}-7 \mathrm{Ni}$ coatings exhibit a compact microstructure without obvious interface inclusions. The microstructures of all the WC-20Cr${ }_{3} \mathrm{C}_{2}-7 \mathrm{Ni}$ coatings are mainly composed of $\mathrm{WC}, \mathrm{Cr}_{3} \mathrm{C}_{2}$, and amorphous $\mathrm{Ni}$ binder. Light color blocky particles are WC, and the dark color blocky particles are $\mathrm{Cr}_{3} \mathrm{C}_{2}$ [11], whose EDS results are shown in Figure 6g,h, respectively. A lamellar structure and boundaries among the particles were obviously revealed in the cross-section of the FC coating, but these microstructural characteristics decrease gradually with the increase in WC grain size, which can be attributed to more serious decarburization of fine WC grains caused by the HVOF plume, which agrees well with the XRD results.

\subsection{The Properties of the WC-20Cr $r_{3} \mathrm{C}_{2}-7 \mathrm{Ni}$ Coatings}

The properties of the three WC-20 $\mathrm{Cr}_{3} \mathrm{C}_{2}-7 \mathrm{Ni}$ coatings are shown in Table 3.

Table 3. Properties of the three WC-20Cr $\mathrm{C}_{2}-7 \mathrm{Ni}$ coatings.

\begin{tabular}{cccc}
\hline Coating & Hardness $\left(\mathbf{H V}_{\mathbf{0 . 3}}\right)$ & Porosity $\mathbf{( \% )}$ & Fracture Toughness $\left(\mathbf{M P a m}^{\mathbf{1} / \mathbf{2}}\right)$ \\
\hline FC & $1167.9 \pm 78.4$ & $0.63 \pm 0.08$ & $2.19 \pm 0.59$ \\
MC & $1093.4 \pm 46.5$ & $1.01 \pm 0.37$ & $2.41 \pm 0.51$ \\
CC & $1045.8 \pm 123.1$ & $1.35 \pm 0.19$ & $4.11 \pm 0.66$ \\
\hline
\end{tabular}

Table 3 suggests that the hardness of the WC-20Cr $3 \mathrm{C}_{2}-7 \mathrm{Ni}$ coating decreased with the increase in WC grain size, while the porosity and fracture toughness showed an opposite trend. It has been reported that $\mathrm{W}_{2} \mathrm{C}$ can both increase the hardness and the brittleness of the corresponding WC-based coatings. Therefore, the lowest porosity and higher $(\mathrm{W}, \mathrm{Cr})_{2} \mathrm{C}$ content of the FC coating may be responsible for its highest hardness and moderate fracture toughness.

\subsection{Abrasive Wear Results}

The specific wear rate of the three WC-20Cr $\mathrm{Cr}_{3}-7 \mathrm{Ni}$ coatings tested with different abrasives and test methods are shown in Figure 7. The three-body-specific wear rates of the WC- $20 \mathrm{Cr}_{3} \mathrm{C}_{2}-7 \mathrm{Ni}$ coatings tested with the $\mathrm{SiO}_{2}$ abrasive were in the range of $1.1 \times 10^{-6}$ to $1.9 \times 10^{-6} \mathrm{~mm}^{3} / \mathrm{Nm}$, with a corresponding increase in WC grain size. In contrast, opposite results, with much larger specific wear rates, are observed in both three-body and two-body abrasive wear tested using the $\mathrm{SiC}$ abrasive and sandpaper, respectively. The two-body-specific wear rate of the $\mathrm{WC}-20 \mathrm{Cr}_{3} \mathrm{C}_{2}-7 \mathrm{Ni}$ coating was about one and two orders higher than that of the three-body wear rate when tested with the $\mathrm{SiC}$ and $\mathrm{SiO}_{2}$ abrasives, respectively.
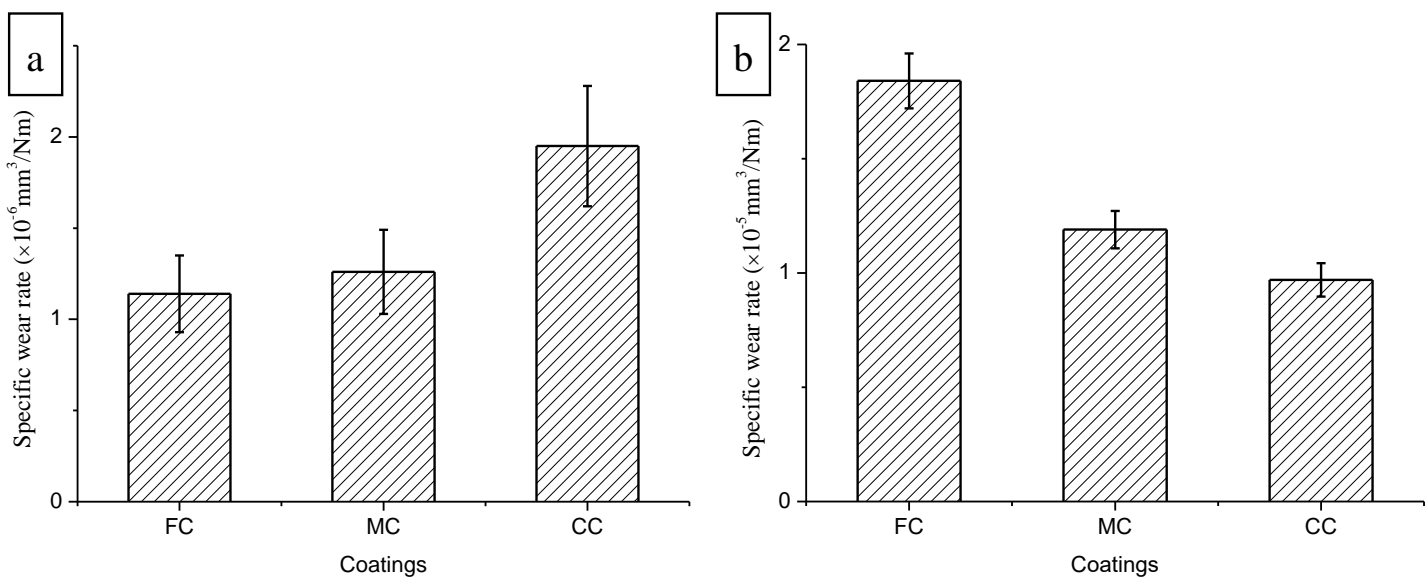

Figure 7. Cont. 


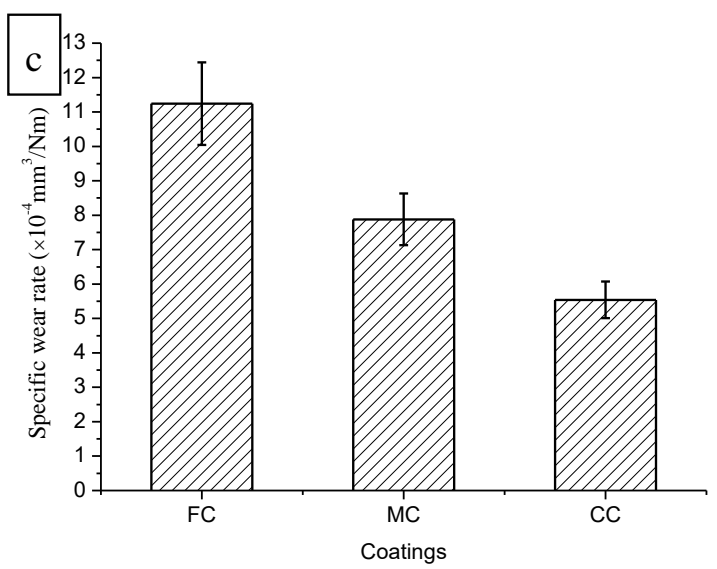

Figure 7. Specific wear rate of the three $\mathrm{WC}-20 \mathrm{Cr}_{3} \mathrm{C}_{2}-7 \mathrm{Ni}$ coatings (a) three-body abrasive wear (180-mesh $\mathrm{SiO}_{2}$ abrasive); (b) three-body abrasive wear (180-mesh $\mathrm{SiC}$ abrasive); (c) two-body abrasive wear (180-mesh $\mathrm{SiC}$ sandpaper).

\section{Discussions}

The typical abrasive worn surface morphologies of the three $\mathrm{WC}-20 \mathrm{Cr}_{3} \mathrm{C}_{2}-7 \mathrm{Ni}$ coatings are shown in Figure 8.
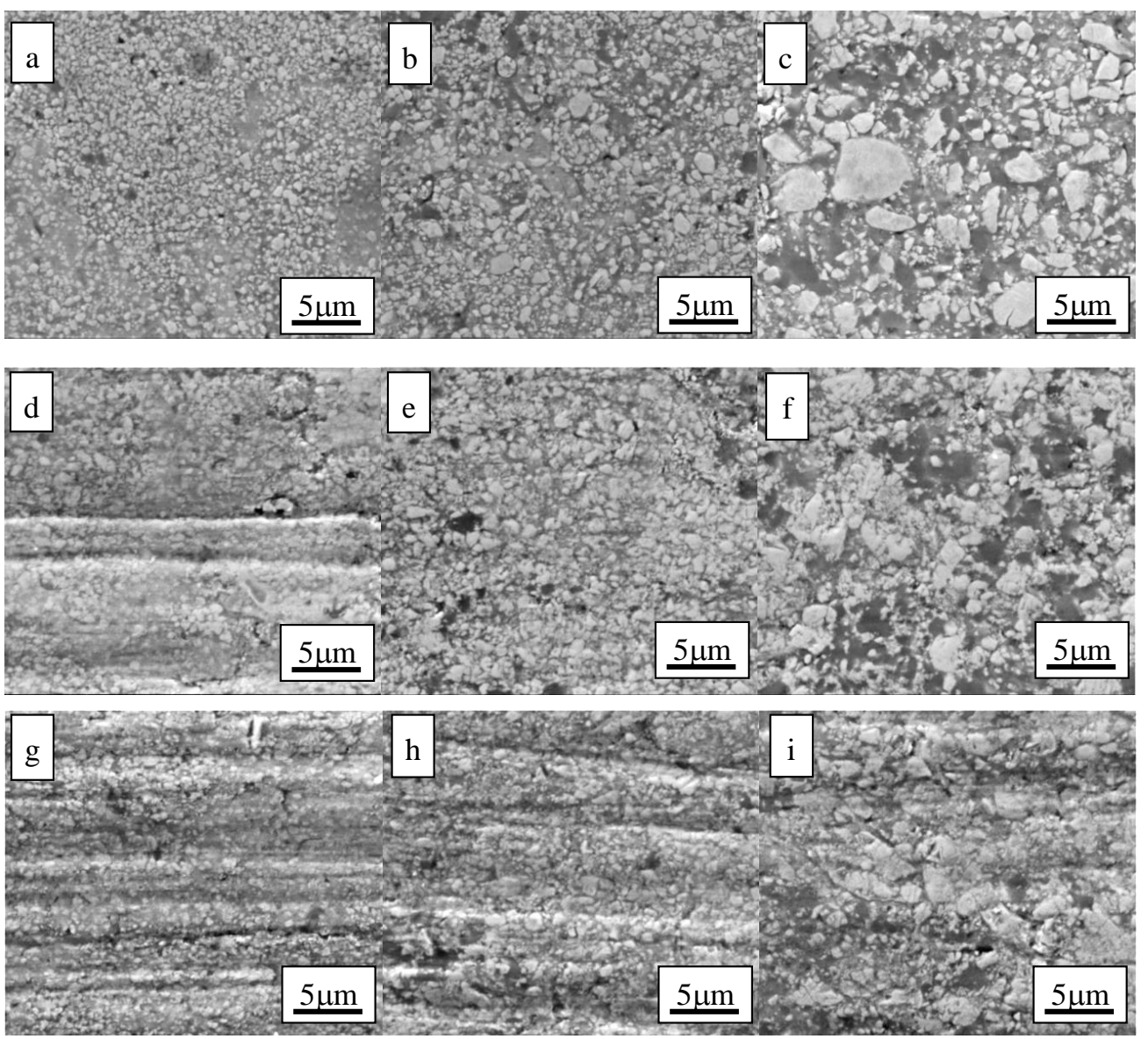

Figure 8. Typical worn surface morphologies of the three WC-20Cr${ }_{3} \mathrm{C}_{2}-7 \mathrm{Ni}$ coatings: $(\mathrm{a}-\mathrm{c})$ three-body abrasive wear (180-mesh $\mathrm{SiO}_{2}$ abrasive); (d-f) three-body abrasive wear (180-mesh $\mathrm{SiC}$ abrasive); (g-i) two-body abrasive wear (180-mesh SiC sandpaper); (a,d,g) FC coating, (b,e,h) MC coating, (c,f,i) CC coating. 
From Figure 8, it can be found that all the worn surfaces show smooth morphologies after three-body abrasive wear tested using the 180 -mesh $\mathrm{SiO}_{2}$ abrasive, but a rougher coating surface with a larger number of grooves was observed when the $\mathrm{SiC}$ abrasive was used in the three-body abrasive wear test. The most uneven worn surface, with a high degree of scratches, can be found on the WC-20Cr $\mathrm{C}_{3} \mathrm{C}_{2}-7 \mathrm{Ni}$ coatings after two-body abrasive wear tested with the $\mathrm{SiC}$ sandpaper. A schematic of the abrasive wear mechanism of the composites is illustrated in Figure 9.

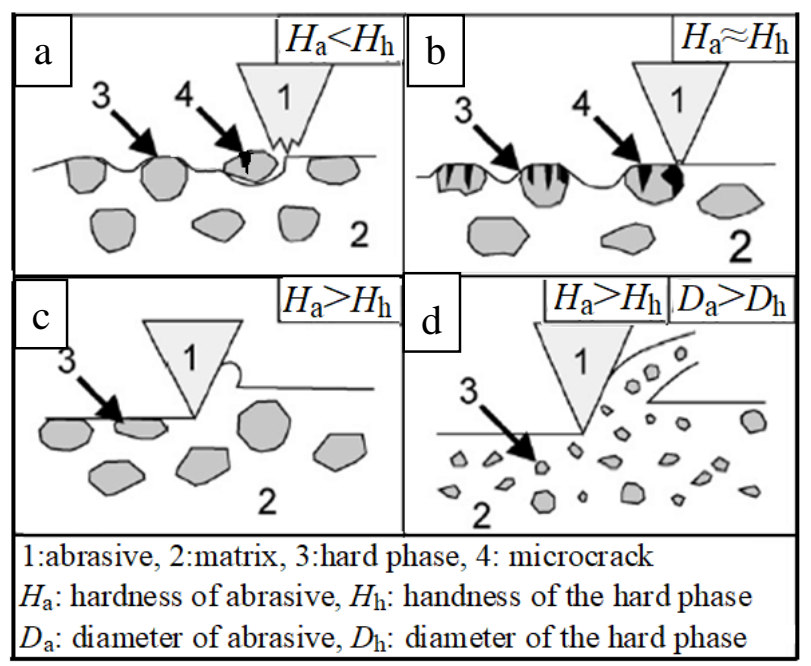

Figure 9. Schematic of the abrasive wear mechanism of the composites.

The abrasive wear process can be divided into two categories according to the relative hardness and size of the abrasive and hard phases [30].

(1) The average size of hard phases of the composite is larger than that of a cross-section of the groove:

The first situation can be divided into three cases according to the relative hardness of the abrasives and hard phases of the worn composite.

- The hardness of the abrasive is lower than that of the hard phase of the composite. The soft binder phase of the composite is preferentially removed, and then the protrusion of the hard phase will be gradually pulled off from the composite without enough support and fixation offered by the binder at a relatively low speed (Figure 9a). At the same instance, a small amount of hard phase and a large area of matrix will be damaged under the repeated reciprocal impact of abrasive particles during the three-body abrasive wear test;

- The hardness of the abrasive particle is similar to that of the hard phase of the composite. The matrix of the composites is preferentially cut, and the hard phases are broken and removed from the binder phase by the repeated impact of the abrasives at a relatively medium speed (Figure 9b);

- The hardness of abrasive particles is higher than that of the hard phase of the composite.

The metal binder and hard particles of the composite can be simultaneously cut by the abrasive, even though the blocking effect of the hard phase relative to the abrasive cutting is stronger than that of the binder phase, which is illustrated in Figure 9c.

(2) The average size of hard phases is smaller than that of a cross-section of the groove.

When the average size of the hard phase is smaller than the cross-section size of the groove, the resistance to the cutting effect of the hard phase relative to the abrasives is not apparent, and the hard phase will be cut within the binder phase by the abrasives at relatively high speed. In this work, when $\mathrm{SiO}_{2}$ (hardness: HV850-1100) was used in the three-body abrasive wear whose hardness is lower than that of the carbides (WC: HV2200-2400, $\mathrm{Cr}_{3} \mathrm{C}_{2}$ : HV1400), but higher than that of the soft Ni 
binder in the WC-20Cr${ }_{3} \mathrm{C}_{2}-7 \mathrm{Ni}$ coating, the abrasive can only penetrate the $\mathrm{Ni}$ binder phase and cut and/or scratch it. With the gradual removal of the Ni binder, the carbides will be broken, undermined, and subsequently pulled out by the repeated impact of the abrasives without getting enough support and fixation from the $\mathrm{Ni}$ binder. In addition, the hardness of the decarburized carbide phases (such as $\mathrm{W}_{2} \mathrm{C}$ ) is higher than that of the original carbide phase [22]. Therefore, the highest decarburization degree of the FC coating among the three HVOF WC-20Cr $\mathrm{C}_{2}-7 \mathrm{Ni}$ coatings partly contributed to its highest hardness (Table 3) and three-body abrasive wear resistance (Figure 7a) when $\mathrm{SiO}_{2}$ was used as the abrasive. The corresponding abrasive wear mechanism is similar to the one illustrated in Figure 9a. In the three WC-20Cr $r_{3} \mathrm{C}_{2}-7 \mathrm{Ni}$ coatings, the various sizes of WC grains result in a different mean free path (MFP) of the Ni binder. Generally, the MFP of the metal binder in a WC-based cermet coating increases with WC grain size. Therefore, the Ni binder of the CC coating is most prone to be cut or scratched by the $\mathrm{SiO}_{2}$ abrasive due to its wider MFP, causing the highest specific wear rate on the CC coating followed by the MC and FC coatings during the three-body abrasive wear test.

On the other hand, when a high hardness abrasive, such as the SiC abrasive (hardness: HV2800) [31], was used, the wear mechanism varied. The high hardness of $\mathrm{SiC}$ can cut both the carbide and binder phases of the WC-based cermet coating, resulting in a different depth and number of grooves on their worn surfaces (Figure $8 \mathrm{~d}-\mathrm{i}$ ), leading to a higher specific wear rate. The average grain size of the WC particles of the FC coating is smaller compared with the MC and CC coatings, leading to a larger proportion of the WC grains having sizes smaller than the cross-sectional dimension of the wear groove of the FC coating. Therefore, the cutting effect of the hard phase relative to the SiC abrasive can be evidenced by the deeper grooves formed on the worn surface of the FC coating (Figure 8d,g). Moreover, the rapid cutting of the hard phase and matrix by the $\mathrm{SiC}$ abrasive can result in a tremendous increase in the specific wear rate of the FC coating. The wear mechanism of the FC coating is illustrated in Figure 9d. With the increase in WC grain size, the resistance to the cutting effect of the hard phase relative to the abrasive particles becomes more significant, and grooves generated on the worn surface of the MC and CC coatings become less noticeable (Figure 8f,i). Thus, the specific wear rates of the WC-20Cr $\mathrm{C}_{2} \mathrm{C}_{2}-7 \mathrm{Ni}$ coating decreases with the increase in its WC grain size in three- and two-body abrasive wear tests conducted with the $\mathrm{SiC}$ abrasive and sandpaper. Ludema and Ajayi [32] proposed that the wear rate of a composite material by abrasion strongly depends on the ratio $(\lambda)$ of the hardness of the abrasive $\left(H_{a}\right)$ and that of the composite material $\left(H_{m}\right)$, which is

$$
\lambda=H_{a} / H_{m}
$$

If $\lambda<0.8$, the specific wear rate is low; if $0.8<\lambda<1.25$, the specific wear rate is moderate, which indicates a transition region; if $\lambda>1.25$, the specific wear rate is high. The ratios $(\lambda)$ between the hardness of the abrasive $\left(H_{a}\right)$ and of the WC-20Cr $\mathrm{C}_{2}-7 \mathrm{Ni}$ coatings $\left(H_{m}\right)$ (Table 3$)$ are shown in Table 4.

Table 4. The ratios $(\lambda)$ between the hardness of the abrasive $\left(H_{a}\right)$ and the $\mathrm{WC}-20 \mathrm{Cr}_{3} \mathrm{C}_{2}-7 \mathrm{Ni}$ coatings $\left(H_{m}\right)$.

\begin{tabular}{ccc}
\hline Coating No. & $\boldsymbol{\lambda}_{\mathbf{1}}\left(\mathrm{SiO}_{\mathbf{2}}\right)$ & $\boldsymbol{\lambda}_{\mathbf{2}}(\mathrm{SiC})$ \\
\hline $\mathrm{FC}$ & $0.73-0.94$ & 2.40 \\
$\mathrm{MC}$ & $0.82-1.01$ & 2.56 \\
$\mathrm{CC}$ & $0.81-1.05$ & 2.68 \\
\hline
\end{tabular}

It is observable in Table 4 that the ratios $\left(\lambda_{1}\right)$ are low when $\mathrm{SiO}_{2}$ was used. Therefore, the wear behavior of the WC-20 $\mathrm{Cr}_{3} \mathrm{C}_{2}-7 \mathrm{Ni}$ coatings belongs to the weak or moderate region. On the other hand, the ratios $\left(\lambda_{2}\right)$ are high when $\mathrm{SiC}$ was used as an abrasive, which leads to a high specific wear rate for the three WC-20Cr $\mathrm{C}_{2}-7 \mathrm{Ni}$ coatings. It could be inferred from Figure 8 that the grooves usually appear on the worn surfaces of the WC-20C $\mathrm{Cr}_{3} \mathrm{C}_{2}-7 \mathrm{Ni}$ coatings when the high-hardness SiC abrasives and sandpaper were used. The two-body-specific wear rates are higher than the three-body ones for 
all the three WC-20C $\mathrm{r}_{3} \mathrm{C}_{2}-7 \mathrm{Ni}$ coatings, even though the same size of the $\mathrm{SiC}$ was used. This is because all the $\mathrm{SiC}$ abrasives on the sandpaper are immovable and the sandpaper is stuck on the surface of the steel wheel, which can cut or scratch the WC-20Cr $\mathrm{C}_{2}-7 \mathrm{Ni}$ coating, resulting in the highest specific wear rate. However, as for the three-body abrasive wear test, there are parts of $\mathrm{SiC}$ abrasives rolling on the worn surface which causes a relatively weak cutting or scratching on the surface of the coatings. Furthermore, the SiC abrasives have a lower plowing stress on the surface of the coating in the three-body abrasive wear test than that of the two-body abrasive wear test due to the soft rubber wheel used in the former test. The different wheel material resulted in different stress conditions, and thus the tests can be accordingly called "low" (for a rubber wheel) and "high" (for a steel wheel) abrasion tests [33]. Therefore, both the rolling and the lower plowing stress of the SiC abrasives on the coating surface are responsible for the lower specific wear rate of the three-body abrasive wear compared with that of the two-body abrasive wear test. However, in the three-body abrasive wear test, there were situations in which some abrasives $\left(\mathrm{SiO}_{2}, \mathrm{SiC}\right.$, or debris from the coating) could get lodged in-between the rubber wheel and the coating and the debris could only slide on the surface of the coating without rolling, similar to that of the two-body abrasive wear. Alternatively, the debris falling-off from the sandpaper and the tested coating can get sandwiched between the SiC sandpaper and cause wear on the coating surface, similar to that of the three-body abrasive wear. Therefore, it can be concluded that two- and three-body abrasive wear may transit between each other depending on the test conditions.

\section{Conclusions}

- The decarburization of WC in the HVOF-sprayed WC-20Cr $\mathrm{C}_{2}-7 \mathrm{Ni}$ coating increased with the decrease in WC grain size, even though the decarburization level of all three $\mathrm{WC}-20 \mathrm{Cr}_{3} \mathrm{C}_{2}-7 \mathrm{Ni}$ coatings was not serious;

- The coating hardness increased, but the fracture toughness and porosity decreased with the decrease in WC grain size;

- The three-body-specific wear rates of the WC-20Cr $\mathrm{C}_{2} \mathrm{C}_{2}-7 \mathrm{Ni}$ coatings increased with the size of the WC grains when the lower hardness $\mathrm{SiO}_{2}$ abrasive was used, but an opposite wear rate trend was observed when the high-hardness $\mathrm{SiC}$ was used in both the two- and the three-body abrasive wear test. In addition, the coatings' three-body-specific wear rates caused by the $\mathrm{SiO}_{2}$ abrasive were less than those caused by the $\mathrm{SiC}$ abrasive with a similar size and slurry concentration;

- The specific wear rates of the WC-20Cr${ }_{3} \mathrm{C}_{2}-7 \mathrm{Ni}$ coatings in the three-body abrasive wear test were less than those in the two-body abrasive wear test when a similar size of the $\mathrm{SiC}$ abrasive was used.

Author Contributions: Conceptualization, Q.W. and X.D.; methodology, Q.W. and S.W.; software, X.D. and Y.Z.; validation, Q.W. and X.D.; formal analysis, Q.W. and C.S.R.; investigation, S.W. and Y.Z.; resources, Q.W.; data curation, S.W. and Y.Z.; writing-original draft preparation, Q.W. and Y.Z.; writing-review and editing, X.D. and C.S.R.; visualization, X.D. and Q.W.; supervision, X.D.; project administration, X.D. and Q.W.; funding acquisition, Q.W. and X.D. All authors have read and agreed to the published version of the manuscript.

Funding: This research was funded by Natural Science Foundation of Hunan Province (2019JJ40045) and Changsha science and technology project (No. kq 1801004).

Conflicts of Interest: The authors declare no conflict of interest.

\section{References}

1. Vashishtha, N.; Khatirkar, R.K.; Sapate, S.G. Tribological behaviour of HVOF sprayed WC-12Co, WC-10Co-4Cr and $\mathrm{Cr}_{3} \mathrm{C}_{2}-25 \mathrm{NiCr}$ coatings. Tribol. Int. 2017, 105, 55-68. [CrossRef]

2. Santacruz, G.; Takimi, A.S.; De Camargo, F.V.; Bergmann, C.P.; Fragassa, C. Comparative study of jet slurry erosion of martensitic stainless steel with tungsten carbide HVOF coating. Metals 2019, 9, 600. [CrossRef]

3. Liu, J.; Bai, X.; Chen, T.; Yuan, C. Effects of cobalt content on the microstructure, mechanical properties and cavitation erosion resistance of HVOF sprayed coatings. Coatings 2019, 9, 534. [CrossRef] 
4. Chen, Y.; Wu, Y.; Hong, S.; Long, W.; Ji, X. The effect of impingement angle on erosion wear characteristics of HVOF sprayed WC-Ni and WC-C $\mathrm{C}_{3} \mathrm{C}_{2}$-Ni cermet composite coatings. Mater. Res. Express 2020, 7, 026503.

5. Cho, J.; Hwang, S.; Kim, K. Corrosion behavior of thermal sprayed WC cermet coatings having various metallic binders in strong acidic environment. Surf. Coat. Technol. 2006, 200, 2653-2662. [CrossRef]

6. Xu, L.; Song, J.; Zhang, X.; Deng, C.; Liu, M.; Zhou, K. Microstructure and corrosion resistance of WC-Based cermet/Fe-based amorphous alloy composite coatings. Coatings 2018, 8, 393. [CrossRef]

7. Jonda, E.; Latka, L.; Pakiela, W. Microstructure and selected properties of $\mathrm{Cr}_{3} \mathrm{C}_{2}-\mathrm{NiCr}$ coatings obtained by HVOF on magnesium alloy substrates. Materials 2020, 13, 2775. [CrossRef] [PubMed]

8. Hou, G.L.; An, Y.L.; Zhao, X.Q.; Chen, J.; Chen, J.M.; Zhou, H.D.; Liu, G. Effect of heat treatment on wear behaviour of WC-(W,Cr) ${ }_{2}$ C-Ni coating. Surf. Eng. 2012, 28, 786-790. [CrossRef]

9. Janka, L.; Berger, L.-M.; Norpoth, J.; Trache, R.; Thiele, S.; Tomastik, C.; Matikainen, V.; Vuoristo, P. Improving the high temperature abrasion resistance of thermally sprayed $\mathrm{Cr}_{3} \mathrm{C}_{2}-\mathrm{NiCr}$ coatings by WC addition. Surf. Coat. Technol. 2018, 337, 296-305. [CrossRef]

10. Mayrhofer, E.; Janka, L.; Mayr, W.P.; Norpoth, J.; Ripoll, M.R.; Groeschl, M. Cracking resistance of $\mathrm{Cr}_{3} \mathrm{C}_{2}-\mathrm{NiCr}$ and $\mathrm{WC}-\mathrm{Cr}_{3} \mathrm{C}_{2}-\mathrm{Ni}$ thermally sprayed coatings under tensile bending stress. Surf. Coat. Technol. 2015, 281, 169-175. [CrossRef]

11. Bolelli, G.; Berger, L.-M.; Bonetti, L.M.; Lusvarghi, L. Comparative study of the dry sliding wear behaviour of HVOF-sprayed WC-(W,Cr) $)_{2} \mathrm{C}-\mathrm{Ni}$ and WC-CoCr hardmetal coatings. Wear 2014, 309, 96-111. [CrossRef]

12. Ishikawa, Y.; Kuroda, S.; Kawakita, J.; Sakamoto, Y.; Takaya, M. Sliding wear properties of HVOF sprayed WC-20\%Cr3C2-7\%Ni cermet coatings. Surf. Coat. Technol. 2007, 201, 4718-4727. [CrossRef]

13. Sidhu, V.P.S.; Goyal, K.; Goyal, R. Hot corrosion behaviour of HVOF-sprayed $93\left(\mathrm{WC}^{-} \mathrm{Cr}_{3} \mathrm{C}_{2}\right)-7 \mathrm{Ni}$ and 83WC-17Co coatings on boiler tube steel in coal fired boiler. Aust. J. Mech. Eng. 2019, 17, 127-132. [CrossRef]

14. Zimmermann, S.; Keller, H.; Schwier, G. New carbide based materials for HVOF spraying. Therm. Spray 2003: Adv. Sci. Appl. Technol. 2003, 1, 5-8.

15. Berget, J.; Rogne, T.; Bardal, E. Erosion-corrosion properties of different WC-Co-Cr coatings deposited by the HVOF process-Influence of metallic matrix composition and spray powder size distribution. Surf. Coat. Technol. 2007, 201, 7619-7625. [CrossRef]

16. Lee, C.W.; Han, J.H.; Yoon, J.; Shin, M.C.; Kwun, S.I. A study on powder mixing for high fracture toughness and wear resistance of WC-Co-Cr coatings sprayed by HVOF. Surf. Coat. Technol. 2010, 204, 2223-2229. [CrossRef]

17. Wang, H.; Song, X.; Liu, X.; Wei, C.; Gao, Y.; Fu, J. Effect of heat-treatment of spray-dried powder on properties of ultrafine-structured WC-Co coating. Surf. Coat. Technol. 2012, 207, 117-122. [CrossRef]

18. Qiao, Y.F.; Fischer, T.E.; Dent, A. The effects of fuel chemistry and feedstock powder structure on the mechanical and tribological properties of HVOF thermal-sprayed WC-Co coatings with very fine structures. Surf. Coat. Technol. 2003, 172, 24-41. [CrossRef]

19. Ding, X.; Ke, D.; Yuan, C.; Ding, Z.; Cheng, X. Microstructure and cavitation erosion resistance of HVOF deposited WC-Co coatings with different sized WC. Coatings 2018, 8, 307. [CrossRef]

20. Al-Mutairi, S.; Hashmi, M.; Yilbas, B.; Stokes, J. Microstructural characterization of HVOF/plasma thermal spray of micro/nano WC-12\%Co powders. Surf. Coat. Technol. 2015, 264, 175-186. [CrossRef]

21. Ghabchi, A.; Varis, T.; Turunen, E.; Suhonen, T.; Liu, X.; Hannula, S.P. Behavior of HVOF WC-10Co4Cr coatings with different carbide size in fine and coarse particle abrasion. J. Therm. Spray Technol. 2010, 19, 368-377. [CrossRef]

22. Usmani, S.; Sampath, S.; Houck, D.L.; Lee, D. Effect of carbide grain size on the sliding and abrasive wear behavior of thermally sprayed WC-Co coatings. Tribol. Trans. 1997, 40, 470-478. [CrossRef]

23. Kumari, K.; Anand, K.; Bellacci, M.; Giannozzi, M. Effect of microstructure on abrasive wear behavior of thermally sprayed WC-10Co-4Cr coatings. Wear 2010, 268, 1309-1319. [CrossRef]

24. Wang, Q.; Xiang, J.; Chen, G.; Cheng, Y.; Zhao, X.; Zhang, S. Propylene flow, microstructure and performance of WC-12Co coatings using a gas-fuel HVOF spray process. J. Mater. Process. Technol. 2013, 213, 1653-1660. [CrossRef]

25. Wang, Q.; Chen, Z.; Li, L.; Yang, G. The parameters optimization and abrasion wear mechanism of liquid fuel HVOF sprayed bimodal WC-12Co coating. Surf. Coat. Technol. 2012, 206, 2233-2241. [CrossRef] 
26. Wang, Q.; Zhang, S.; Cheng, Y.; Xiang, J.; Zhao, X.; Yang, G. Wear and corrosion performance of WC-10Co4Cr coatings deposited by different HVOF and HVAF spraying processes. Surf. Coat. Technol. 2013, 218, 127-136. [CrossRef]

27. Evans, A.; Wilshaw, T.R. Quasi-static solid particle damage in brittle solids-I. Observations analysis and implications. Acta Metall. 1976, 24, 939-956. [CrossRef]

28. Guilemany, J.; De Paco, J.; Miguel, J.; Nutting, J. Characterization of the $\mathrm{W}_{2} \mathrm{C}$ phase formed during the high velocity oxygen fuel spraying of a WC+ 12 pct Co powder. Metall. Mater. Trans. A 1999, 30, 1913-1921. [CrossRef]

29. Berger, L.-M.; Saaro, S.T.; Kasparova, M.; Zahalka, F. Microstructure and properties of HVOF-sprayed WC-(W,Cr) $)_{2}$ C-Ni coatings. J. Therm. Spray Technol. 2008, 17, 395-403. [CrossRef]

30. Totten, G.E. Friction, lubrication, and wear technology. In ASM Handbook; Batchelor, A.W., Liang, H., et al., Eds.; ASM International: Materials Park, OH, USA, 2017; Volume 18, pp. 223-224.

31. Asl, M.S.; Kakroudi, M.G.; Noori, S. Hardness and toughness of hot pressed $\mathrm{ZrB}_{2}-\mathrm{SiC}$ composites consolidated under relatively low pressure. J. Alloy. Compd. 2015, 619, 481-487. [CrossRef]

32. Kenneth, C.L.; Oyelayo, O.A. Friction, Wear, Lubrication: A Textbook in Tribology, 2nd ed.; CRC Press: Boca Raton, FL, USA, 2018.

33. Houdkova, S.; Zahalka, F.; Kasparova, M.; Berger, L.M. Comparative study of thermally sprayed coatings under different types of wear conditions for hard chromium replacement. Tribol. Lett. 2011, 43, 139-154. [CrossRef]

(C) 2020 by the authors. Licensee MDPI, Basel, Switzerland. This article is an open access article distributed under the terms and conditions of the Creative Commons Attribution (CC BY) license (http://creativecommons.org/licenses/by/4.0/). 